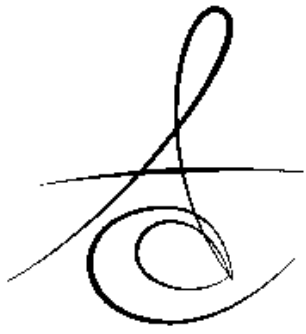

\title{
EVALUATION OF EFFECT OF IMPRESSION TECHNIQUES TO SATISFACTION OF EDENTULOUS PATIENTS TREATED WITH IMPLANT-RETAINED OVERDENTURES: A PILOT STUDY
}

\section{İMPLANT DESTEKLİ OVERDENTURELARLA TEDAVİ EDİLEN TAM DİŞSİZ HASTALARDA ÖLÇÜ TEKNİĞİNİN MEMNUNİYETE ETKİSİNİN DEĞERLENDİRİLMESİ: BİR PİLOT ÇALIŞMA}

\author{
Arş. Gör. Dr. Emre TOKAR* \\ Yrd. Doç. Dr. Serdar POLAT* \\ Prof. Dr. Bülent ULUDAĞ**
}

Makale Kodu/Article code: 2861

Makale Gönderilme tarihi: 23.05.2016

Kabul Tarihi: 25.10 .2016

\begin{abstract}
Aim: The implant-retained mandibular overdentures are standard care of the edentulous patients. Function, phonetics and satisfaction of the patient are decisive to acquire prospering treatment results. Passive fit between the implants and the denture framework is important for restoration of the implants. Accurate impression is primary factor to obtain fitted denture. Several impression techniques (single stage, double, and functional impression techniques) described making impression of the implant-retained overdentures. The aim of this study was to evaluate influence of two different implant-retained overdenture impression techniques to quality of life of the patients.
\end{abstract}

Materials and Method: Six women edentulous patients participated in this study. 2 implant-retained overdentures were fabricated using two different impression techniques per patient. The first overdentures were produced using the single stage close tray impression technique. After 6 months, the functional impression technique was used to fabricate the second overdentures. 13 questions were asked to the patients about both of their dentures in the first follow up visits those two days after the delivery of their overdentures. The Mann-Whitney $U$ statistical analysis was performed on the acquired data.

Results: The patients satisfied with the performance of both of the overdentures. Half of the participants complained soreness of the gums under the overdenture that was fabricated using the close tray impression technique. Other questionnaire items were shown no statistically significant differences.

Conclusion: The single stage close tray, and the functional impression techniques are used confidently to fabricate the implant-retained mandibular overdentures. The functional impression technique decreased chair time of the post-insertion maintenance.

Keywords: Overdenture, Precision attachment, Dental implant, Fabrication technique, Impression

\section{öz}

Amaç: İmplant destekli overdenture uygulamaları tam dişsiz hastalar için standart tedavi yöntemlerindendir. Fonksiyon, fonasyon ve hasta memnuniyeti başarılı tedavi sonuçları elde etmek için belirleyicidir. İmplant restorasyonlarında, implant ve protez altyapısı arasındaki pasif uyum önem arzetmektedir. Tam uyumlu protezler için ölçünün doğruluğu birincil faktördür. İmplant destekli overdenturelarda ölçünün alınması için birkaç ölçü tekniği (tek aşama, çift aşama ve fonksiyonel ölçü teknikleri) tanımlanmıştır. Bu çalışmanın amacı, iki farklı implant destekli overdenture ölçü tekniğinin hastaların yaşam kalitesine olan etkisinin değerlendirilmesidir.

Materyal ve Metot: Çalışmamıza altı kadın dişsiz hasta katılmıştır. Her hasta için iki farklı ölçü tekniği kullanılarak iki tane implant destekli overdenture protez yapılmıştır. Birinci overdenturelar, tek aşama kapalı kaşık ölçü tekniği kullanılarak hazırlanmıştır. Altı ay sonra fonksiyonel ölçü tekniği kullanılarak ikinci overdenture protezler yapılmıştır. Protezlerin tesliminden sonraki ilk kontolde hastalara protezleri ile ilgili 13 soruluk anket yöneltilmiştir. Elde edilen veriler Mann-Whitney $U$ istatistiksel analizi uygulanarak değerlendirilmiştir.

Bulgular: Hastalar hazırlanan iki protezin de performansından memnun kalmışlardır. Katılımcıların yarısı kapalı kaşık tekniği ile yapılan overdenture protezin altındaki yumuşak dokudaki yaralardan yakınmışlardır. Anketteki diğer sorular istatistiksel olarak anlamlı fark göstermemiştir. Sonuç: Tek aşama kapalı kaşık ölçü tekniği ile fonksiyonel ölçü tekniği implant destekli overdentureları hazırlamak için güvenle kulanılabilirler. Fonksiyonel ölçü tekniği protez tesliminden sonra harcanan hasta başı zamanını azaltmıştır.

Anahtar Kelimeler: Overdenture, Hassas tutucu, Dental implant, Yapım tekniği, Ölçü

\footnotetext{
${ }^{*}$ Gazi Üniversitesi, Diş Hekimliği Fakültesi, Protetik Diş Tedavisi AD, Ankara

** Uludağ Ağız ve Diş Sağlığı Polikliniği, Ankara
} 


\section{INTRODUCTION}

Edentulism is a handicap that relates to oral function and psychological impact on the quality of life. ${ }^{1}$ Restoration of the edentulous jaw can be perform fabrication of fixed or removable prosthesis. ${ }^{2}$ The implant-retained overdentures (IROs) are widely accepted treatment modality to rehabilitate the edentulous maxilla and mandible. ${ }^{3,4}$ IROs are different from the conventional complete dentures which support from both of the mucosa and the implants. ${ }^{5}$

Two implant-retained mandibular overdenture (IRMO) is suggested to be the standard procedure for edentulous mandibles by McGill ${ }^{6}$ and York $^{7}$ consensus reports. Two implants are cost-effective, and sufficient for the denture stability and retention. ${ }^{6,7}$ Distribution of occlusal forces, function, phonetics, esthetics, oral hygiene, and satisfaction of the patient are important to acquire successful treatment outcomes. Functional and non-functional loads must be distributed equally to both of the denture bearing areas and the dental implants for prospering IROs. Because, the excessive loads may induce the bone microdamage and resorption. 8

Many attachment systems are commercially presented to fabricate an IRO. ${ }^{9}, 10$ Bar and stud attachments are frequently used to attach the IROs to the dental implants.9, 11 The choice of attachment design depends on bone morphology, capability of stress distribution, desired retention value, patient expectations, cost, and soft tissue pain. ${ }^{12-14}$

Moreover, differences of resiliency between the residual ridge mucosa and the implant have to be taken into account for selection of the attachment type. $^{15}$

Accuracy of the impression is crucial to achieve passive fit between the implants and the denture framework. ${ }^{16,17}$ Thus, an accurate impression provides to produce well adapted denture base and peripheral seal. These ensure sufficient tissue support to the denture. ${ }^{17-21}$ The overdenture impression have to record the denture bearing areas simultaneously with accurate positioning of the implant components. ${ }^{22}$ In the literature, three types of impression techniques have been described for impression of IROs. Firstly, the single stage impression procedure that is used with a closed or an open impression trays. These techniques are the frequently used method for
IROs. ${ }^{23-25}$ Secondly, a double-impression technique for only two IROs has been recommended, using a zinc oxide eugenol (ZOE) impression paste and a polyether impression material. ${ }^{2,}{ }^{26}$ Finally, the third type of impression technique is a functional impression technique (FIT) for IROs. ${ }^{27-30}$

One type impression material, especially polyether or vinyl polysiloxane impression materials, is used to transfer the implant positions from the oral cavity to the master cast for single stage impression techniques. $^{31}$ However, an IRO has different characteristics from the complete denture due to combination of the tissue support and the implant retention. $^{2}$

The double impression techniques have been described and it has been focused on the relation between the soft tissue supporting structures and the implants. $^{22,} 32$ On the contrary, FITs have been reported to record the alveolar mucosa in a functional state and the implant components correctly. ${ }^{27-31}$

Although several techniques and case reports have been reported for making impression of IROs, any clinical studies which are evaluating effect of the implant impression techniques on satisfaction of the patient are lacking. Because, the impression is one of the important stages to fabricate accurate IROs. The aim of this pilot study was to compare the clinical results of the single stage closed tray impression technique (CTIT) ${ }^{25}$ and a $\mathrm{FIT}^{30}$ for IRMOs. The hypothesis is to define which overdenture impression technique is better for satisfaction of the patient.

\section{MATERIALS AND METHOD}

Six women patients who had severely resorbed edentulous mandible participated in this study. The patients were treated with IROs. Two IRMOs with ball attachment were made using two different impression techniques six months interval for all participants. A study protocol by Ankara University Faculty of Dentistry Institutional Review Board and informed consent from the subjects were recorded for this pilot study.

$\mathrm{CTIT}^{25}$ was used to produce the master cast of the first IRMO. Preliminary impressions of the jaws were made with an irreversible hydrocolloid (CA37; Cavex Holland BV, Haarlem, The Netherlands) and poured with a Type III dental stone (Begostone; Bego 
Dental, Bremen, Germany). A custom acrylic resin (Meliodent; Heraus Kulzer, Dormagen, Germany) impression tray was prepared for the mandible. Healing caps (Zimmer Dental Inc, Carlsbad, CA) were unscrewed and the ball abutments (Zimmer Dental Inc) were tightened onto the implants (Zimmer Dental Inc). The ball abutment transfers (Zimmer Dental Inc) were attached directly to the abutments (Figure $1 \mathrm{~A}$ ). Definitive impression was made with a medium bodied polyether impression material (Impregum; 3M Espe, Monrovia, CA) using the custom impression tray. The impression was removed from the mouth, and the ball abutment transfers (Zimmer Dental Inc) remained into the impression. The ball abutment replicas (Zimmer Dental Inc) were placed onto the abutment transfers that have been captured in the impression (Figure 1B). Master cast of the mandible was generated with a Type IV dental stone (Begostone). The master casts of the jaws were mounted to semi adjustable articulator using inter-maxillary records. Denture tooth arrangement was set using an anatomic artificial teeth (Major, Major Prodotti Dentari, Torino, Italy). IRMO with the ball attachment was fabricated, and used by the patient for a period of six months. This time interval was set to ensure complete adaptation of the patients to the overdenture according to evidence based knowledge.
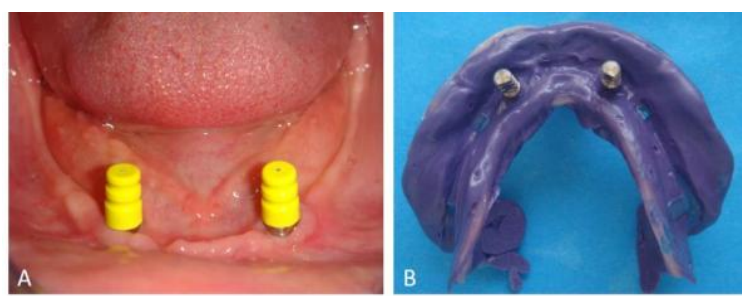

Figure 1. A) Insertion of ball abutment transfers on the implants for CTIT, B) Final impression of the CTIT.

After the six months, the second IRMO was fabricated using $\mathrm{FIT}^{30}$. The preliminary impression of the jaws was made again with an irreversible hydrocolloid (CA37). A custom acrylic resin (Meliodent) impression tray was prepared with an opening in the implant areas, and positive notches were formed on the residual ridge areas for ease to support the tray intraorally with finger pressure (Figure $2 \mathrm{~A}$ ). Border of the custom impression tray was molded using modeling plastic impression compound (Impression
Compound; Kerr Italia S.p.A., Salerno, Italy), and the impression of the alveolar mucosa was made with a Zinc Oxide Eugenol (ZOE) impression paste (S.S. White; Prima Dental Group, Gloucester, UK) (Figure 2B). Upon completion of the impression procedure, excess of the impression paste was removed from around the ball abutments (Zimmer Dental Inc), and the custom impression tray was seated attentively to the mouth. The ball abutment transfers (Zimmer Dental Inc) were attached directly to the abutments. A light-bodied elastomeric impression material (Oranwash L; Zhermack SpA Badia Polesine (RO), Italy) was injected around the ball abutment transfers (Zimmer Dental Inc) through the access openings of the custom impression tray. The definitive impression of the mandible was completed by inserting a stock tray over the custom impression tray using a heavybodied elastomeric impression material (Zetaplus; Zhermack SpA Badia Polesine (RO), Italy). The impression was removed from the mouth with the ball abutment transfers (Zimmer Dental Inc). Smooth transition between the impression materials was confirmed. The ball abutment replicas (Zimmer Dental Inc) were placed onto the abutment transfers that have been captured in the impression (Figure 2C). Mandible cast was poured with a Type IV dental stone (Begostone). IRMO with ball attachment was fabricated with same procedure of the first IRMO.

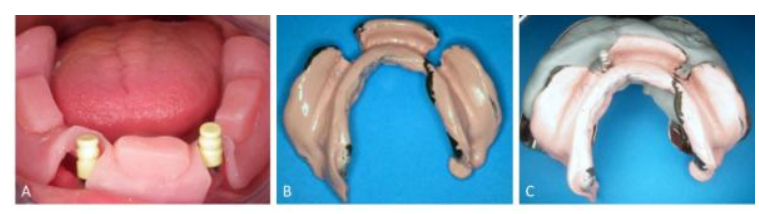

Figure 2. A) Intraoral adaptation check of custom acrylic resin tray for FIT, B) Impression of the alveolar mucosa with modelling plastic and zinc oxide eugenol, C) Final impression of the FIT.

Both techniques were applied and two-IRMO were generated with same methods for all patients.

13 questions were asked to the patients about both of their dentures in the first follow up visits those two days after the delivery of their prosthesis (Table 1 ). The questionnaire items refer to problems and symptoms during the previous days. The questionnaire was covered 3 domains: ${ }^{33}$ 
Table 1. Questionnaire used by the subject

\begin{tabular}{|c|c|c|}
\hline 1. & $\begin{array}{l}\text { Do you have any problems with your new dentures? } \\
\text { Yes } \square \quad \text { No } \square\end{array}$ & \\
\hline 2. & $\begin{array}{l}\text { Looseness of the lower denture } \\
\text { Yes } \square \text { No } \square\end{array}$ & \\
\hline 3. & $\begin{array}{l}\text { Soreness of the gums under the lower denture } \\
\text { Not a problem } \square \quad \text { Some problem }\end{array}$ & A problem $\square$ \\
\hline 4. & $\begin{array}{l}\text { Food gets under the lower denture } \\
\text { Not a problem } \square \quad \text { Some problem } \square\end{array}$ & A problem \\
\hline 5. & $\begin{array}{l}\text { The lower denture moves when you talking } \\
\text { Not a problem } \\
\text { Some problem }\end{array}$ & A problem \\
\hline 6. & $\begin{array}{l}\text { Difficulty chewing with the back teeth } \\
\text { Not a problem }\end{array}$ & \\
\hline 7. & $\begin{array}{l}\text { The dentures interfe } \square \text { with your speech } \\
\text { Not a problem } \quad \square \quad \text { Some problem }\end{array}$ & A problem \\
\hline 8. & $\begin{array}{l}\text { The dentures feel too much of a mouthful } \\
\text { Not a problem } \square \quad \text { Some problem } \square\end{array}$ & A problem \\
\hline 9. & $\begin{array}{l}\text { Your face aches after yvearing them for some time } \\
\text { Not a problem } \\
\text { Some problem }\end{array}$ & A problem \\
\hline 10 & $\begin{array}{l}\text { How do your dentures look compared with natural t } \\
\text { Worse } \square \quad \text { The Same }\end{array}$ & th? \\
\hline 11 & $\begin{array}{l}\text { How do your new dentures look ompared with you } \\
\text { Worse } \square \quad \text { The Same }\end{array}$ & $\begin{array}{l}\text { Id dentures? } \\
\text { Better } \square\end{array}$ \\
\hline 12 & $\begin{array}{l}\text { How do your new dentures chew ompared with yo } \\
\text { Worse } \square \quad \text { The Same } \square\end{array}$ & $\begin{array}{l}\text { natural teeth? } \\
\text { Better } \square\end{array}$ \\
\hline 13 & $\begin{array}{l}\text { How do your new dentures chew ompared with y } \\
\text { Worse } \square \text { The Same }\end{array}$ & $\begin{array}{l}\text { old dentures? } \\
\text { Better } \square\end{array}$ \\
\hline
\end{tabular}

Complaints, mandibular denture. This domain consisted of 4 items concerning functional problems, for example, "looseness" or "soreness of the gums under the denture." Each item could be answered on a 3 -point rating scale $(0=$ not a problem, $1=$ some problem, 2 = a problem), which was also used for the next domain.

Functional complaints in general. This domain consisted of 6 items concerning functional problems with dentures as a whole, for example, "the dentures interfere with speech" or "the dentures feel too much of a mouthful."

Esthetics. This domain consisted of 2 items concerning the esthetics of the dentures themselves, for example, "the dentures look satisfactory compared to natural teeth" to "the dentures look satisfactory compared to previous dentures." Each item could be answered on a 3-point rating scale ( 0 = better, $1=$ the same, 2 = worse).

The Mann Whitney $U$ test was used for statistical analysis because of a few number of observation. Statistical significance was set at $p<0.05$ and differences between the dentures were compared (Table 2, Figure 3).

\section{RESULTS}

The results of statistical analysis are presented in Table 2. These indicate the number of patients who had a problem, and the mean score related to such items. Mean statistically difference was found item \# 3 of "Soreness of the gums under the lower denture" (Table 2, Figure 3). Three out of six patients were answered item \# 3 differently for IRMOs made with different impression techniques. They chose "some problem" option for the first IRMO that was made with CTIT. However, same participants chose "not a problem" option for the denture made with FIT. The other participants' answers of item \# 3 were same. Another significant differences were not found when compared to first and second IRMOs (Table 2, Figure 3).

Table 2. Differences in complaint scores between the first IRMOs and the second IRMOs

\begin{tabular}{|c|c|c|c|}
\hline $\begin{array}{c}\text { Item } \\
\text { Number }\end{array}$ & Mann-Whitney U & $\mathbf{Z}$ & $\begin{array}{c}\text { Asymp. Sig. } \\
\text { (2-tailed) }\end{array}$ \\
\hline 1. & 18 & 0 & 1 \\
\hline 2. & 18 & 0 & 1 \\
\hline 3. & $\mathbf{6}$ & $\mathbf{- 2 , 2 9 7 8}$ & $\mathbf{0 , 0 2 1 6}$ \\
\hline 4. & 13 & $-0,8908$ & 0,373 \\
\hline 5. & 18 & 0 & 1 \\
\hline 6. & 12 & $-1,4771$ & 0,1396 \\
\hline 7. & 12 & $-1,4771$ & 0,1396 \\
\hline 8. & 18 & 0 & 1 \\
\hline 9. & 18 & 0 & 1 \\
\hline 10. & 18 & 0 & 1 \\
\hline 11. & 18 & 0 & 1 \\
\hline 12. & 17,5 & $-0,1231$ & 0,902 \\
\hline 13. & 15,5 & $-0,527$ & 0,5982 \\
\hline
\end{tabular}

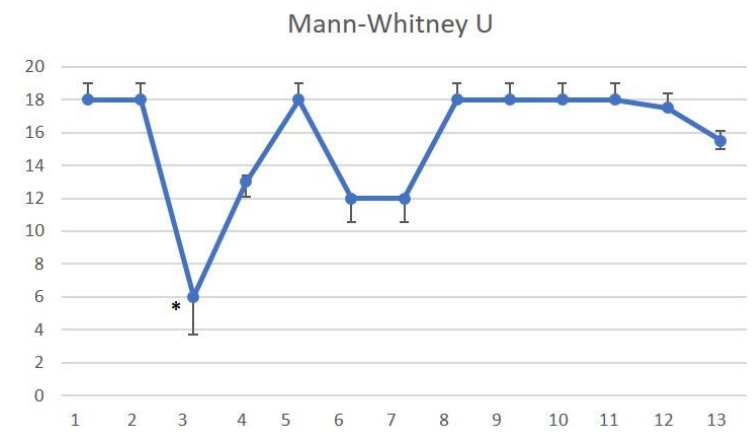

Figure 3. Graphic of statistical analysis. (Mann-Whitney U)

\section{DISCUSSION}

The attendees of this study accepted the overdentures that were fabricated using both of the impression techniques. Two IRMOs were fabricated using two different impression techniques but same laboratory procedures were applied. Second

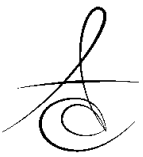


overdentures were fabricated six months later from insertion of primary overdentures due to obtain adaptation of the attendees to the IRMOs according to evidence based knowledge. The patients had got to face little problems about their IRMOs according to questionnaire results.

Rehabilitation of completely edentulous patients has been significantly increased quality of life. ${ }^{1}$ The conventional complete dentures and IROs have been used by clinicians to restore resorbed edentulous arches. The mandibular arch has been highlighted more complicate than the maxillary arch. Positive impact to quality of life of the edentulous patients with IROs are provided compared to conventional complete dentures. ${ }^{4,34}$

Interforaminal two-IRMOs have been declared as standard of care in the edentulous mandibles. ${ }^{6,7}$ Also, more than three implant could have been used to retain IRMOs. ${ }^{2}$ Patient satisfaction and treatment cost have been decisive to choice of denture design and number of implants.

Basically, four types of attachments (bar, stud, magnetic, and telescopic attachments) may be used to connect an IRO on the implants. ${ }^{10}$ Studs, bars, and combination of bars with other attachments are usually used by the dentists. Also, stud attachments are frequently preferred by the clinicians because of versatilities, easy to use and low costs. ${ }^{11}$ In the present study, the ball attachment that is one type of the studs was used to attach IROs to the implants.

IROs can be supported from either the mucosa or the retained implants. ${ }^{5}$ Therefore, survival rates of the dental implants may be increased well balanced distribution of the loads. Structure, number, location, and inclination of the implants, supporting alveolar crests, and soft tissue areas, type of attachments can be influenced load distribution characteristics. ${ }^{13,14}$

The clinicians take into account efficient tissue support to produce IROs as well as conventional complete dentures. ${ }^{16}$ Furthermore, passive fit between the implants and the overdentures ensures equal load distribution to the implants and the denture bearing areas. Accuracy of the impression is primary factor to acquire fitted dentures. ${ }^{22}$ Various factors can affect them such as implants (e.g., number, connection type, angulation), and impression technique (e.g., impression tray, impression material, splinting). ${ }^{17}$

Hobkirk et al. $^{33}$ evaluated satisfaction of edentulous patients treated with conventional and implant retained complete mandibular dentures. They concluded that seven years after the implant treatment patients' satisfaction with IRMOs was better than the conventional complete dentures. Also, the authors noted more chairside time was needed to treat IRMO cases compared to conventional complete dentures.

Three types of impression techniques (single stage impression technique ${ }^{23-25}$, double impression technique $2,22,26,32$, and functional impression technique ${ }^{27-30}$ ) have been explained for IROs. Single stage impression techniques are the frequently used procedure for IROs. Closed and open tray impression techniques have been defined as a subgroups of single stage impression technique. ${ }^{23-25}$ Several authors have been found that CTIT presented more precise master cast compared to open tray impression technique. ${ }^{17-19}$ Conversely, some researches have shown that open tray impression technique produced more accurate master cast than closed tray impression technique. ${ }^{20}$,

${ }^{21}$ In the current study, CTIT used making impression of first IROs.

FIT records accurately the denture bearing areas in a functional state and the implant structures. ${ }^{30}$ This technique has some advantages, like chair time decreases in the post insertion maintenance, ${ }^{28-30}$ and provides the accurate relation between the implants and the residual ridges ${ }^{28}$. However, it is technique sensitive, and the clinician have to assure the correct placement of the stock tray over the custom acrylic tray with ZOE in the second stage of the procedure. FIT is more involved and time consuming at the impression phase compared to the single stage techniques.

In this study, fitting of the overdentures were subjectively evaluated by two senior prosthodontists. There was found no significant differences except of one questionnaire item either $\mathrm{CTIT}^{25}$ or $\mathrm{FIT}^{30}$ and the patients satisfied with both of the IRMOs. Questionnaire item \#3 "Soreness of the gums under the lower denture" was crucial to gain satisfaction of the patient for IRMOs. Because, soreness of the gum was annoying for the patients and increases frequency of the post insertion appointments. ${ }^{29}$ This pilot study showed that further multi-center studies have to assess using a clinical scoring scale addition to the questionnaire used by subjects. 


\section{CONCLUSION}

The presented study showed that CTIT and FIT can be used securely to fabricate IRMOs. Attendees of the study were pleased both of the overdentures. The complaints about soreness decreased at the follow-up visits and the patients satisfied after the treatment. However, FIT is precise to record the border relation with different impression materials. The patients' complaints about soreness were not explicit for overdenture fabricated with FIT. Also, stages of this technique are more time consuming and techniquesensitive. The overall findings of this pilot study are encouraging, and a larger well documented multicenter prospective study is necessary.

\section{Acknowledgements}

This research was presented at the $16^{\text {th }}$ Congress of Balkan Association of Stomatological Society (BASS) Bucharest, Romania, April 2011.

\section{KAYNAKLAR}

1. Mack F, Schwahn C, Feine JS, Mundt T, Bernhardt $\mathrm{O}$, John $U$ et al. The impact of tooth loss on general health related to quality of life among elderly Pomeranians: results from the study of health in Pomerania (SHIP-O). Int J Prosthodont 2005;18:414-9.

2. Mericske-Stern RD, Taylor TD, Belser U. Management of the edentulous patient. Clin Oral Implants Res 2000;11:108-25.

3. Thomason JM, Kelly SA, Bendkowski A, Ellis JS. Two implant retained overdentures--a review of the literature supporting the McGill and York consensus statements. J Dent 2012;40:22-34.

4. Sivaramakrishnan G, Sridharan K. Comparison of implant supported mandibular overdentures and conventional dentures on quality of life: A systematic review and meta-analysis of randomized controlled studies. Aust Dent J 2016;61:482-8.

5. Naert I, Quirynen M, Theuniers G, van Steenberghe D. Prosthetic aspects of osseointegrated fixtures supporting overdentures. A 4-year report. J Prosthet Dent 1991;65:671-80.

6. Feine JS, Carlsson GE, Awad MA, Chehade A, Duncan WJ, Gizani $S$ et al. The McGill Consensus Statement on Overdentures. Montreal, Quebec,
Canada. May 24-25, 2002. Int J Prosthodont 2002;15:413-4.

7. Thomason JM, Feine J, Exley C, Moynihan P, Muller $\mathrm{F}$, Naert I et al. Mandibular two implant-supported overdentures as the first choice standard of care for edentulous patients--the York Consensus Statement. Br Dent J 2009;207:185-6.

8. Pesqueira A, Goiato M, Gennari-Filho $H$, Monteiro D, Dos Santos D, Haddad $M$ et al. The use of stress analysis methods to evaluate the biomechanics of oral rehabilitation with implants. J Oral Implantol 2014;40:217-28.

9. Heckmann SM, Winter W, Meyer M, Weber HP, Wichmann MG. Overdenture attachment selection and the loading of implant and denture-bearing area. Part 1: In vivo verification of stereolithographic model. Clin Oral Implants Res 2001;12:617-23.

10. Porter JA, Jr., Petropoulos VC, Brunski JB. Comparison of load distribution for implant overdenture attachments. Int J Oral Maxillofac Implants 2002;17:651-62.

11. Heckmann SM, Winter W, Meyer M, Weber HP, Wichmann MG. Overdenture attachment selection and the loading of implant and denture-bearing area. Part 2: A methodical study using five types of attachment. Clin Oral Implants Res 2001;12:640-7.

12. Alsabeeha NH, Payne AG, Swain MV. Attachment systems for mandibular two-implant overdentures: a review of in vitro investigations on retention and wear features. Int J Prosthodont 2009;22:429-40.

13. Celik G, Uludag B. Effect of the Number of Supporting Implants on Mandibular Photoelastic Models with Different Implant-Retained Overdenture Designs. J Prosthodont 2014;23:37480.

14. Tokar E, Uludag B. Load Transfer Characteristics of Various Designs of Three-Implant-Retained Mandibular Overdentures. Int J Oral Maxillofac Implants 2015;30:1061-7.

15. Ichikawa $T$, Horiuchi M, Wigianto R, Matsumoto $N$. In vitro study of mandibular implant-retained overdentures: the influence of stud attachments on load transfer to the implant and soft tissue. Int J Prosthodont 1996;9:394-9.

16. Wee AG, Aquilino SA, Schneider RL. Strategies to achieve fit in implant prosthodontics: a review of the literature. Int J Prosthodont 1999;12:167-78. 
17. Lee YJ, Heo SJ, Koak JY, Kim SK. Accuracy of different impression techniques for internalconnection implants. Int J Oral Maxillofac Implants 2009;24:823-30.

18. Burawi G, Houston F, Byrne D, Claffey N. A comparison of the dimensional accuracy of the splinted and unsplinted impression techniques for the Bone-Lock implant system. J Prosthet Dent 1997;77:68-75.

19. Humphries RM, Yaman P, Bloem TJ. The accuracy of implant master casts constructed from transfer impressions. Int $\mathrm{J}$ Oral Maxillofac Implants 1990;5:331-6.

20. Carr AB. Comparison of impression techniques for a five-implant mandibular model. Int J Oral Maxillofac Implants 1991;6:448-55.

21. Herbst D, Nel JC, Driessen $\mathrm{CH}$, Becker PJ. Evaluation of impression accuracy for osseointegrated implant supported superstructures. J Prosthet Dent 2000;83:555-61.

22. Gregory-Head B, LaBarre E. Two-step pick-up impression procedure for implant-retained overdentures. J Prosthet Dent 1999;82:615-6.

23. De La Cruz JE, Funkenbusch PD, Ercoli C, Moss ME, Graser GN, Tallents RH. Verification jig for implant-supported prostheses: A comparison of standard impressions with verification jigs made of different materials. J Prosthet Dent 2002;88:32936.

24. Ganddini MR, Schejtman N, Ercoli C, Graser GN. Prosthodontic application for implant carriers. J Prosthet Dent 2004;92:399-402.

25. Chee W, Jivraj S. Impression techniques for implant dentistry. Br Dent J 2006;201:429-32.

26. Jannesar $S$, Siadat $H$, Alikhasi $M$. A dual impression technique for implant overdentures. J Prosthodont 2007;16:327-9.

27. Uludag B, Celik G. An alternative impression technique for implant-retained overdentures. J Prosthet Dent 2006;96:377-8.

28. Uludag B, Ozturk O, Celik G. Alternate functional impression technique for implant-retained overdentures. J Prosthet Dent 2007;97:242-3.

29. Uludag B, Sahin V. A functional impression technique for an implant-supported overdenture: a clinical report. J Oral Implantol 2006;32:41-3.

30. Uludag B, Celik G, Sahin V, Ozturk O. Fabrication of implant-assisted restorations utilizing functional impression techniques: case reports. J Oral Implantol 2007;33:297-304.

31. Uludag B. An alternate pressure-free functional impression technique for implant-retained overdentures. J Oral Implantol 2010;36:205-7.

32. White KC, Ramus DL. Two-stage impression technique for overdentures. J Prosthet Dent 1989;61:452-7.

33. Hobkirk JA, Abdel-Latif $\mathrm{HH}$, Howlett J, Welfare R, Moles DR. Prosthetic treatment time and satisfaction of edentulous patients treated with conventional or implant-supported complete mandibular dentures: a case-control study (part 1). Int J Prosthodont 2008;21:489-95.

34. Korkmaz C, Atay A. Evaluation of two different attachment system used for maxillary overdenture: two case reports. J Dent Fac Atatürk Uni 2014; 9:33-7.

\section{Yazışma Adresi}

Arş.Gör.Dr. Emre TOKAR

Gazi Üniversitesi

Diş Hekimliği Fakültesi

Protetik Diş Tedavisi AD

Bişkek Cd. (8. Cd.) 82. Sk.

No:4 06510 Emek-ANKARA

Email: emretokar@yahoo.com

Tel: +903122034192 